\title{
Comparison of the effects of cholecalciferol and calcitriol on calcium metabolism and bone turnover in Chinese postmenopausal women with vitamin D insufficiency
}

\author{
Hao ZHANG, Qi-ren HUANG* , Jie-mei GU, Wei-wei HU, Yu-juan LIU, Yun-qiu HU, Zhen-lin ZHANG \\ Metabolic Bone Disease and Genetic Research Unit, Department of Osteoporosis and Bone Diseases; Shanghai Jiao Tong University, \\ Affiliated Sixth People's Hospital; Shanghai 200233, China
}

\begin{abstract}
Aim: To compare the effects of cholecalciferol $(800 \mathrm{IU} / \mathrm{d})$ and calcitriol $(0.25 \mu \mathrm{g} / \mathrm{d})$ on calcium metabolism and bone turnover in Chinese postmenopausal women with vitamin D insufficiency.

Methods: One hundred Chinese postmenopausal women aged 63.8 \pm 7.0 years and with serum 25-hydroxyvitamin D [25(OH)D] concentration $<30 \mathrm{ng} / \mathrm{mL}$ were recruited. The subjects were divided into 2 groups based on the age and serum 25(OH)D concentration: 50 subjects (group A) received cholecalciferol $(800 \mathrm{IU} / \mathrm{d}$ ), and 50 subjects (group B) received calcitriol $(0.25 \mu \mathrm{g} / \mathrm{d}$ ) for 3 months. In addition, all the subjects received Caltrate $\mathrm{D}$ (calcium plus $125 \mathrm{IU}$ cholecalciferol) daily in the form of one pill. The markers of calcium metabolism and bone turnover, including the serum levels of calcium, phosphorus, alkaline phosphatase, intact parathyroid hormone, $25(\mathrm{OH}) \mathrm{D}$ and $\beta$-CrossLaps of type I collagen containing cross-linked C-telopeptide ( $\beta$-CTX), were measured before and after the intervention.

Results: After the 3-month intervention, the serum 25(OH)D concentration in group A was significantly increased from 16.01 \pm 5.0 to $20.02 \pm 4.5 \mathrm{ng} / \mathrm{mL}$, while that in group $B$ had no significant change. The serum calcium levels in both the groups were significantly increased (group A: from $2.36 \pm 0.1$ to $2.45 \pm 0.1 \mathrm{mmol} / \mathrm{L}$; group B: from $2.36 \pm 0.1$ to $2.44 \pm 0.1 \mathrm{mmol} / \mathrm{L}$ ). The levels of serum intact parathyroid hormone in both the groups were significantly decreased (group A: from $48.56 \pm 12.8$ to $39.59 \pm 12.6 \mathrm{pg} / \mathrm{mL}$; group B: from $53.67 \pm 20.0$ to $40.32 \pm 15.4 \mathrm{pg} / \mathrm{mL}$ ). The serum levels of $\beta$-CTX in both the groups were also significantly decreased (group A: from $373.93 \pm 135.3$ to $325.04 \pm 149.0 \mathrm{ng} / \mathrm{L}$; group B: from $431.00 \pm 137.1$ to $371.74 \pm 185.0 \mathrm{ng} / \mathrm{L}$ ).

Conclusion: We concluded that both cholecalciferol $(800 \mathrm{IU} / \mathrm{d})$ and calcitriol $(0.25 \mathrm{\mu g} / \mathrm{d})$ plus Caltrate $\mathrm{D}$ modifies the serum calcium and bone turnover markers in Chinese postmenopausal women with vitamin D insufficiency. In addition, cholecalciferol (800 IU/d) plus Caltrate D significantly increased the serum 25(OH)D concentration.
\end{abstract}

Keywords: cholecalciferol; calcitriol; calcium metabolism; bone turnover; parathyroid hormone; 25 -hydroxyvitamin D; $\beta$-CrossLaps of type I collagen containing cross-linked C-telopeptide ( $\beta$-CTX); postmenopausal women

Acta Pharmacologica Sinica (2012) 33: 490-495; doi: 10.1038/aps.2011.172; published online 12 Mar 2012

\section{Introduction}

The vitamin D receptor is found in bone, most tissues and cells in the body. Vitamin D deficiency is a common health problem that increases the risk of many common and serious diseases, including some cancers, type 1 diabetes, cardiovascular disease, and osteoporosis ${ }^{[1]}$. Vitamin D is important for maintaining bone health because it stimulates the synthesis of osteopontin and alkaline phosphatase and inhibits osteoblast

\footnotetext{
* To whom correspondence should be addressed.

E-mail qirenhuang@yahoo.com

Received 2011-10-10 Accepted 2011-11-15
}

apoptosis ${ }^{[2]}$. Vitamin D status is best evaluated by measuring the serum concentration of 25 -hydroxyvitamin $\mathrm{D}[25(\mathrm{OH}) \mathrm{D}]^{[3]}$. Most specialties define vitamin D deficiency as $25(\mathrm{OH}) \mathrm{D}$ levels below $20 \mathrm{ng} / \mathrm{mL}^{[4]}$. A level of $25(\mathrm{OH}) \mathrm{D}$ of $21-29 \mathrm{ng} / \mathrm{mL}$ indicates a vitamin D insufficiency whereas a level of $30 \mathrm{ng} / \mathrm{mL}$ or greater indicates vitamin D sufficiency ${ }^{[5]}$. The prevalence of atrophic skin changes in older adults is concomitant with an increased probability of lower 25(OH)D levels ${ }^{[6]}$. Unlike those of other nutrients, dietary sources of vitamin $\mathrm{D}$ are limited. Therefore, most people require supplements such as cholecalciferol (vitamin $\mathrm{D}_{3}$ ) to meet the recommended intake ${ }^{[7]}$. Current guidelines for vitamin $\mathrm{D}$ intakes vary around the world. 
The National Osteoporosis Foundation (NOF) recommends an intake of 800 to 1000 international units (IU) of vitamin D per day for adults 50 years and older ${ }^{[8]}$. Hanley et al ${ }^{[9]}$ have suggested that adults over 50 years old are at a moderate risk for vitamin D deficiency and recommended the use of a supplement with at least $800-1000 \mathrm{IU}$ of vitamin $\mathrm{D}_{3}$. In an expert roundtable discussion, it was agreed that the daily vitamin D intake should be approximately $800 \mathrm{IU}$ for most postmenopausal women ${ }^{[10]}$. One study indicated that serum $25(\mathrm{OH}) \mathrm{D}$ increased with cholecalciferol supplementation and nearly plateaued after 3-4 months of intervention ${ }^{[11]}$. In elderly people, diminished renal function due to aging leads to a decrease in renal conversion to $1,25(\mathrm{OH})_{2} \mathrm{D}_{3}{ }^{[12]}$. Calcitriol $\left[1,25(\mathrm{OH})_{2} \mathrm{D}_{3}\right]$ plays an important role in promoting bone formation, and D-hormone analogs prevent falls to a greater extent than does ordinary vitamin D. Therefore, the use of D-hormone analogs has been advocated for the treatment of osteoporosis in many studies ${ }^{[13-15]}$. Because patients who are treated with $0.5 \mu \mathrm{g} / \mathrm{d}$ or $1.0 \mu \mathrm{g} / \mathrm{d}$ of calcitriol tend to develop hypercalcinuria, serum and urinary calcium levels should be examined regularly, and the calcitriol regime should be examined intermittently. Patients are frequently treated with 0.25 $\mu \mathrm{g} / \mathrm{d}$ of calcitriol in China, especially elderly patients with osteoporosis. Hurst et $a l^{[16]}$ concluded that correcting vitamin $\mathrm{D}$ deficiency in older women may suppress the age-induced acceleration in bone turnover and may reduce bone resorption. However, Seemans et $a l^{[17]}$ observed that despite the stratification of different vitamin $\mathrm{D}$ receptor genotypes, cholecalciferol supplementation throughout the winter months did not affect bone turnover markers in young or old people. The aim of the current study was to compare the effects of cholecalciferol at $800 \mathrm{IU}$ per day and calcitriol at $0.25 \mu \mathrm{g}$ per day on calcium metabolism and bone turnover in Chinese postmenopausal women who are vitamin D insufficient.

\section{Materials and methods}

\section{Subjects and study design}

This was an open-label, controlled clinical trial. The study was approved by the Ethics Committee of the Shanghai Jiao Tong University Affiliated Sixth People's Hospital.

One hundred healthy, independent, ambulatory, postmenopausal female volunteers were recruited from community centers. All participants were of Han ethnicity and had lived in Shanghai for more than 30 years. Postmenopausal women over 50 years of age were eligible for the study, and the serum $25(\mathrm{OH}) \mathrm{D}$ concentrations of all subjects were less than $30 \mathrm{ng} / \mathrm{mL}$. All subjects were given a physical examination and were found to be in good health. No participant was receiving treatment or had medical complications that were known to affect bone metabolism, including hyperthyroidism, diabetes mellitus, primary hyperparathyroidism, renal failure, pituitary diseases, and adrenal diseases. All the women had taken less than $600 \mathrm{mg} /$ day of calcium and less than 600 IU/day of vitamin D within the 3 months prior to enrollment. The subjects were divided into two groups based on age and serum $25(\mathrm{OH}) \mathrm{D}$ concentrations. Fifty of the subjects received $800 \mathrm{IU} /$ day of cholecalciferol (Cholecalciferol, Xingsha Pharmaceuticals Co, Xiamen, China), and the other fifty matched subjects received $0.25 \mu \mathrm{g} /$ day of calcitriol (Calcitriol, Roche Pharmaceuticals Co, Shanghai, China), as group A and group B, respectively. All subjects received 1 pill/day of Caltrate D (containing $600 \mathrm{mg}$ of calcium and $125 \mathrm{IU}$ of vitamin $\mathrm{D}_{3}$, Wyeth Pharmaceuticals, Health Care Products, Suzhou, China). Because the Caltrate D contained 125 IU of vitamin $\mathrm{D}_{3}$, group A was provided $925 \mathrm{IU}$ of cholecalciferol altogether. The study period was from December 2009 to March 2010, which was during the end of winter and the beginning of spring in China.

\section{Laboratory tests}

Fasting blood samples were obtained at baseline and at the end of the study. Blood routine, erythrosedimentation, liver function, renal function and fasting blood-glucose were examined to exclude subjects who had other factors that may affect their vitamin D status. Markers of calcium metabolism and bone turnover were assessed before and after the three-month intervention, including serum calcium $(\mathrm{Ca})$, phosphorus $(\mathrm{P})$, alkaline phosphatase (AKP) (using the HITACHI7600-020 automatic biochemistry analyzer), intact parathyroid hormone (normal, 15-65 pg/mL, intact PTH Kit, Roche Diagnostics, Mannheim, Switzerland), concentrations of $25(\mathrm{OH}) \mathrm{D}$ (25 hydroxy vitamin D3 Kit, Roche Diagnostics, Mannheim, Switzerland; using a Cobase 6000 electrochemiluminescence analyzer) and $\beta$-CrossLaps of type I collagen containing crosslinked C-telopeptide ( $\beta$-CTX) ( $\beta$-CrossLaps Kit, Roche Diagnostics, Mannheim, Switzerland). The coefficients of variability $(\mathrm{CV})$ of serum $\mathrm{Ca}, \mathrm{P}, \mathrm{AKP}, \mathrm{PTH}, 25(\mathrm{OH}) \mathrm{D}$, and $\beta$-CTX were $2.4 \%, 3.3 \%, 5.1 \%, 9.5 \%, 4.0 \%$, and $3.4 \%$, respectively.

\section{Statistical analysis}

Data are represented as the mean \pm standard deviation (SD). Comparisons of the result before and after treatments were calculated using paired Student's $t$-test for the parametric data of each group. The independent sample $t$-tests were used to compare the serum parameters before and after the treatments of groups A and B, respectively. The independent sample $t$-test was used to compare the difference in the change pattern over time between group A and group B, starting at the treatment baseline. All calculations were performed using SPSS ver 11.0 software (SPSS Inc, Chicago, IL, USA). Data were considered statistically significant at a value of $P<0.05$.

\section{Results}

The baseline characteristics of 100 postmenopausal women are shown in Table 1. The mean age of the subjects was 63.8 \pm 7.0 years old, the mean menopausal period was $13.7 \pm 8.7$ years, and the mean $25(\mathrm{OH}) \mathrm{D}$ level was $16.84 \pm 5.4 \mathrm{ng} / \mathrm{mL}$.

\section{Serum parameters of groups $A$ and $B$}

The baseline characteristics showed no differences between the two groups, except that $\beta$-CTX was significantly higher in group $\mathrm{B}$ than that in group $\mathrm{A}(P<0.05)$ (Table 2$)$. 
Table 1. Baseline characteristics of 100 postmenopausal women.

\begin{tabular}{lrrc}
\hline & Mean & SD & $\begin{array}{c}\text { Range } \\
\text { (upper limit, } \\
\text { lower limit) }\end{array}$ \\
& & & \\
\hline Age (year) & 63.8 & 7.0 & $(51.3,79.9)$ \\
Duration of menopause (year) & 13.7 & 8.7 & $(1.0,40.0)$ \\
Height $(\mathrm{cm})$ & 154.5 & 5.5 & $(139.0,166.5)$ \\
Weight $(\mathrm{kg})$ & 58.1 & 9.5 & $(36.0,80.0)$ \\
$\mathrm{BMI}\left(\mathrm{kg} / \mathrm{cm}^{2}\right)$ & 24.3 & 3.5 & $(15.6,33.3)$ \\
$\mathrm{Ca}(\mathrm{mmol} / \mathrm{L})$ & 2.36 & 0.1 & $(2.14,2.58)$ \\
P $(\mathrm{mmol} / \mathrm{L})$ & 1.19 & 0.1 & $(0.91,1.47)$ \\
AKP $(\mathrm{mmol} / \mathrm{L})$ & 66.78 & 19.3 & $(20.00,113.00)$ \\
$25(\mathrm{OH}) \mathrm{D}(\mathrm{ng} / \mathrm{mL})$ & 16.84 & 5.4 & $(5.34,29.48)$ \\
PTH $(\mathrm{pg} / \mathrm{mL})$ & 51.46 & 17.1 & $(20.41,101.3)$ \\
$\beta-\mathrm{CTX}(\mathrm{ng} / \mathrm{L})$ & 403.54 & 137.8 & $(127.00,837.00)$ \\
\hline
\end{tabular}

BMI: bone mass index.

Table 2. Baseline characteristics of group A and B.

\begin{tabular}{lccc}
\hline & Group A & Group B & P value \\
\hline$n$ & 45 & 47 & \\
Age (year) & $63.3 \pm 6.8$ & $64.5 \pm 6.9$ & $>0.05$ \\
Duration of menopause (year) & $13.4 \pm 8.1$ & $14.3 \pm 9.3$ & $>0.05$ \\
Height $(\mathrm{cm})$ & $155.0 \pm 5.4$ & $154.0 \pm 5.6$ & $>0.05$ \\
Weight $(\mathrm{kg})$ & $58.2 \pm 9.4$ & $57.3 \pm 9.8$ & $>0.05$ \\
BMI $\left(\mathrm{kg} / \mathrm{cm}^{2}\right)$ & $24.2 \pm 3.6$ & $24.1 \pm 3.4$ & $>0.05$ \\
Ca $(\mathrm{mmol} / \mathrm{L})$ & $2.36 \pm 0.1$ & $2.36 \pm 0.1$ & $>0.05$ \\
P $(\mathrm{mmol} / \mathrm{L})$ & $1.19 \pm 0.1$ & $1.20 \pm 0.2$ & $>0.05$ \\
AKP $(\mathrm{mmol} / \mathrm{L})$ & $67.78 \pm 19.4$ & $66.55 \pm 20.6$ & $>0.05$ \\
$25(\mathrm{OH}) \mathrm{D}(\mathrm{ng} / \mathrm{mL})$ & $16.01 \pm 5.0$ & $17.31 \pm 5.5$ & $>0.05$ \\
PTH $(\mathrm{pg} / \mathrm{mL})$ & $48.56 \pm 12.8$ & $53.67 \pm 20.0$ & $>0.05$ \\
B-CTX $(\mathrm{ng} / \mathrm{L})$ & $373.93 \pm 135.3$ & $431.00 \pm 137.1$ & $<0.05$ \\
\hline
\end{tabular}

BM: bone mass index. Values shown in boldface are statistically significant.

After the 3-month intervention, the mean serum 25(OH)D increased from $16.01 \pm 5.0 \mathrm{ng} / \mathrm{mL}$ to $20.02 \pm 4.5 \mathrm{ng} / \mathrm{mL}$ in group A $(P<0.01)$. However, the mean serum $25(\mathrm{OH}) \mathrm{D}$ showed no significant difference before and after the intervention per- formed on group $\mathrm{B}(P>0.05)$ (Table 3$)$. In group $\mathrm{A}$, serum $25(\mathrm{OH}) \mathrm{D}$ less than $20 \mathrm{ng} / \mathrm{mL}$ was detected in $76 \%$ of women $(34 / 45)$, including $18 \%$ of women $(8 / 45)$ with less than 10 $\mathrm{ng} / \mathrm{mL}$ vitamin $\mathrm{D}$, and 25(OH)D between 20 and $30 \mathrm{ng} / \mathrm{mL}$ was indicated in $24 \%$ of women $(11 / 45)$ previous to the intervention. Serum $25(\mathrm{OH}) \mathrm{D}$ less than $20 \mathrm{ng} / \mathrm{mL}$ was indicated in $49 \%$ of group A (22/45), including $2 \%$ of women $(1 / 45)$ with less than $10 \mathrm{ng} / \mathrm{mL}$ vitamin $\mathrm{D}$, and 25(OH)D between 20 and $30 \mathrm{ng} / \mathrm{mL}$ was indicated in $51 \%$ of group A $(23 / 45)$ after the intervention. In group $B$, serum $25(\mathrm{OH}) \mathrm{D}$ less than $20 \mathrm{ng} / \mathrm{mL}$ was indicated in $66 \%$ of women $(31 / 47)$, including $13 \%$ of women (6/47) with less than $10 \mathrm{ng} / \mathrm{mL}$ vitamin $\mathrm{D}$, and $25(\mathrm{OH}) \mathrm{D}$ between 20 and $30 \mathrm{ng} / \mathrm{mL}$ was indicated in $34 \%$ of women $(16 / 47)$ before the intervention. Serum $25(\mathrm{OH}) \mathrm{D}$ less than $20 \mathrm{ng} / \mathrm{mL}$ was indicated in $85 \%$ of group B (40/47), including $6 \%$ of group B (3/47) with less than $10 \mathrm{ng} / \mathrm{mL}$ vitamin $\mathrm{D}$, and vitamin D 25(OH)D between 20 and $30 \mathrm{ng} / \mathrm{mL}$ was indicated in $15 \%$ of group B (7/47) after the intervention.

After the three-month intervention, both groups showed a significant increase in serum Ca levels (all $P<0.01)$ that were within the normal range. The AKP levels of groups $A$ and $B$ also showed a significant increase $(P<0.05$ and $P<0.01$, respectively). The serum PTH and $\beta$-CTX levels showed a significant decrease in both groups (all $P<0.01$ and all $P<0.05$ ) (Table 3).

We compared the serum parameters between the two groups after the 3-month intervention and identified significantly higher levels of serum $25(\mathrm{OH}) \mathrm{D}$ in group A than those of group B $(P<0.01)$ (Table 4$)$. We compared the difference in

Table 4. Compared serum parameters of the two groups after the treatment.

\begin{tabular}{lccc}
\hline & $\begin{array}{c}\text { After intervention } \\
\text { of group A }(n=45)\end{array}$ & $\begin{array}{c}\text { After intervention } \\
\text { of group B }(n=47)\end{array}$ & $P$ value \\
\hline $\mathrm{Ca}(\mathrm{mmol} / \mathrm{L})$ & $2.45 \pm 0.1$ & $2.44 \pm 0.1$ & $>0.05$ \\
$\mathrm{P}(\mathrm{mmol} / \mathrm{L})$ & $1.22 \pm 0.1$ & $1.24 \pm 0.1$ & $>0.05$ \\
$\mathrm{AKP}(\mathrm{mmol} / \mathrm{L})$ & $73.27 \pm 16.8$ & $74.02 \pm 17.3$ & $>0.05$ \\
$25(\mathrm{OH}) \mathrm{D}(\mathrm{ng} / \mathrm{mL})$ & $20.02 \pm 4.5$ & $16.22 \pm 3.8$ & $<0.01$ \\
$\mathrm{PTH}(\mathrm{pg} / \mathrm{mL})$ & $39.59 \pm 12.6$ & $40.32 \pm 15.4$ & $>0.05$ \\
$\beta$-CTX $(\mathrm{ng} / \mathrm{L})$ & $325.04 \pm 149.0$ & $371.74 \pm 185.0$ & $>0.05$ \\
\hline
\end{tabular}

Values shown in boldface are statistically significant.

Table 3. Changes in the serum parameters of the two groups before and after treatment.

\begin{tabular}{|c|c|c|c|c|c|c|}
\hline & $\begin{array}{l}\text { Baseline of group A } \\
\qquad(n=45)\end{array}$ & $\begin{array}{l}\text { After intervention } \\
\text { of group } \mathrm{A}(n=45)\end{array}$ & $P$ value & $\begin{array}{l}\text { Baseline of group B } \\
\qquad(n=47)\end{array}$ & $\begin{array}{l}\text { After intervention } \\
\text { of group B }(n=47)\end{array}$ & $P$ value \\
\hline $\mathrm{Ca}(\mathrm{mmol} / \mathrm{L})$ & $2.36 \pm 0.1$ & $2.45 \pm 0.1$ & $<0.01$ & $2.36 \pm 0.1$ & $2.44 \pm 0.1$ & $<0.01$ \\
\hline $\mathrm{P}(\mathrm{mmol} / \mathrm{L})$ & $1.19 \pm 0.1$ & $1.22 \pm 0.1$ & $>0.05$ & $1.20 \pm 0.2$ & $1.24 \pm 0.1$ & $>0.05$ \\
\hline $\operatorname{AKP}(\mathrm{mmol} / \mathrm{L})$ & $67.78 \pm 19.4$ & $73.27 \pm 16.8$ & $<0.05$ & $66.55 \pm 20.6$ & $74.02 \pm 17.3$ & $<0.01$ \\
\hline $25(\mathrm{OH}) \mathrm{D}(\mathrm{ng} / \mathrm{mL})$ & $16.01 \pm 5.0$ & $20.02 \pm 4.5$ & $<0.01$ & $17.31 \pm 5.5$ & $16.22 \pm 3.8$ & $>0.05$ \\
\hline
\end{tabular}

Values shown in boldface are statistically significant. 
the change pattern between the two groups over time starting at treatment baseline and found that only serum $25(\mathrm{OH}) \mathrm{D}$ showed a significant difference between group A and group B (Table 5).

Table 5. Comparison of the changes before and after treatment between group A and group B.

\begin{tabular}{lccc}
\hline & $\begin{array}{c}\text { Changed pattern } \\
\text { after intervention } \\
\text { of group A }(n=45)\end{array}$ & $\begin{array}{c}\text { Changed pattern } \\
\text { after intervention } \\
\text { of group B }(n=47)\end{array}$ & $P$ value \\
\hline $\mathrm{Ca}(\mathrm{mmol} / \mathrm{L})$ & $0.09 \pm 0.1$ & $0.08 \pm 0.1$ & $>0.05$ \\
$\mathrm{P}(\mathrm{mmol} / \mathrm{L})$ & $0.02 \pm 0.1$ & $0.04 \pm 0.2$ & $>0.05$ \\
$\mathrm{AKP}(\mathrm{mmol} / \mathrm{L})$ & $5.49 \pm 15.1$ & $7.47 \pm 15.0$ & $>0.05$ \\
$25(\mathrm{OH}) \mathrm{D}(\mathrm{ng} / \mathrm{mL})$ & $4.00 \pm 6.0$ & $-1.09 \pm 5.1$ & $<0.01$ \\
$\mathrm{PTH}(\mathrm{pg} / \mathrm{mL})$ & $-13.35 \pm 13.6$ & $-8.97 \pm 10.3$ & $>0.05$ \\
$\beta-\mathrm{CTX}(\mathrm{ng} / \mathrm{L})$ & $-48.89 \pm 129.5$ & $-59.26 \pm 150.3$ & $>0.05$ \\
\hline
\end{tabular}

Values shown in boldface are statistically significant.

\section{Withdrawal from the study and adverse events}

Eight participants (5 participants in the group A and 3 participants in the group B) discontinued the study. In the group A, two participants withdrew without providing a reason, two participants were lost during follow-up, and one participant withdrew because of cholelithiasis and shingles that, according to the clinical judgment, were attributed to a severe adverse event but were not related to the use of study medication. In the group $B$, three participants withdrew without providing a reason. After the 3-month treatment, the concentration of serum $\mathrm{Ca}, \mathrm{P}$, and the total AKP activities in the two groups remained within normal ranges.

\section{Discussion}

Many studies have shown that $40 \%$ to $100 \%$ of elderly people in the US and Europe suffer from vitamin D deficiencies ${ }^{[18,19]}$. More than $50 \%$ of postmenopausal women had levels of 25-hydroxyvitamin $\mathrm{D}$ that were lower than $30 \mathrm{ng}$ per milliliter $^{[19]}$. Low levels of $25(\mathrm{OH}) \mathrm{D}$ are associated with a significant decrease in the absorption of intestinal calcium and induced secondary hyperparathyroidism ${ }^{[18,20]}$. Secondary hyperparathyroidism may stimulate the transformation of preosteoclasts into mature osteoclasts, causing osteoporosis and increasing the risk of fracture ${ }^{[19]}$. Our results show that serum Ca levels increased and serum PTH levels decreased significantly after supplementation with cholecalciferol (800 IU/d) plus Caltrate $\mathrm{D}$ for three months. Kuwabara et al ${ }^{[21]}$ discovered that the supplementation of $200 \mathrm{mg}$ of calcium with 800 IU of vitamin $\mathrm{D}_{3}$ daily for one month significantly lowered the serum PTH levels compared with the supplementation of only $200 \mathrm{mg}$ of calcium daily. Seemans et $a l^{[17]}$ identified that in the winter, the endpoint serum PTH level to be significantly lower in 3 cholecalciferol-supplemented groups (cholecalciferol 200 IU,
$400 \mathrm{IU}$, and $600 \mathrm{IU})$ compared with the placebo group, though other bone turnover markers were not affected. An increased rate of bone turnover is associated with low bone mass ${ }^{[22]}$ and an increased risk of bone fracture ${ }^{[23]}$. Higher levels of serum CTX indicate an increase in bone resorption and bone fragility ${ }^{[24]}$. Total AKP is primarily a nonspecific marker of bone formation. Our results show that after supplementing with 800 IU per day of cholecalciferol for three months, serum AKP levels increased significantly, and serum $\beta$-CTX levels decreased. These results indicate that $800 \mathrm{IU}$ per day of cholecalciferol is effective for stimulating bone formation and reducing bone resorption. Hurst et $a l^{[16]}$ has shown that vitamin D-deficient women who were administered 4000 IU of cholecalciferol daily for 6 months displayed a suppression of age-induced bone turnover and bone resorption. However, some studies have shown cholecalciferol supplementation have no effect on bone turnover markers ${ }^{[17,21]}$.

Oral vitamin D supplementation increases bone mineral density and appears to reduce the risk of hip and other nonvertebral fractures. Therefore, it is reasonable to supply 800-1000 IU/d of vitamin D to older individuals ${ }^{[25]}$. Heaney et $a l^{[11]}$ found that after supplementing with 1000, 5000, and $10000 \mathrm{IU}$ of cholecalciferol, the serum 25(OH)D levels of every group plateaued after 3-4 months intervention. Therefore, Hanley et $a l^{[9]}$ suggested measuring the serum $25(\mathrm{OH}) \mathrm{D}$ after 3-4 months of adequate intervention. In our study, the mean concentration of serum 25(OH)D increased from 16.01 to 20.02 $\mathrm{ng} / \mathrm{mL}$ after 3 months of supplementation with cholecalciferol. However, $49 \%$ of this group was still vitamin D-deficient. The cholecalciferol group in our study was provided with 125 IU of Caltrate D. Therefore, the total cholecalciferol reached 925 IU, and the dose was not sufficient to achieve adequate $25(\mathrm{OH}) \mathrm{D}$ concentrations. Similarly, Pignotti et al ${ }^{[26]}$ have shown that after supplementation with 400 IU of cholecalciferol and 1200 mg of calcium for 3 months in sunny Brazil, the concentration of serum 25(OH)D increased from $18.7 \mathrm{ng} / \mathrm{mL}$ to $23.8 \mathrm{ng} / \mathrm{mL}$. However, $86.2 \%$ of the supplemented group did not reach optimal levels $(30.0 \mathrm{ng} / \mathrm{mL})$ of $25(\mathrm{OH}) \mathrm{D}$. Kuwabara et al ${ }^{[21]}$ discovered that after supplementation with 800 IU of cholecalciferol and $200 \mathrm{mg}$ of calcium for 1 month, serum $25(\mathrm{OH}) \mathrm{D}$ levels in old men and women increased from $9.7 \mathrm{ng} / \mathrm{mL}$ to $19.3 \mathrm{ng} / \mathrm{mL}$, although $60 \%$ of the subjects remained vitamin D-deficient. However, Chapuy et al ${ }^{[27]}$ reported that after supplementation with $800 \mathrm{IU}$ of cholecalciferol and $1200 \mathrm{mg}$ of calcium for 6 months, serum 25(OH)D levels increased from $9.2 \mathrm{ng} / \mathrm{mL}$ to $30.0 \mathrm{ng} / \mathrm{mL}$. The varied results of these different studies may be associated with the dose of cholecalciferol, the period of study, the intake of calcium and differences associated with the population. Hanley et al ${ }^{[9]}$ systematically reviewed 168 potentially relevant vitamin D papers from 1996 to 2008 and concluded that vitamin D was necessary for the prevention of osteoporosis. They recommended an intake of cholecalciferol for high-risk and older adults ranging from 800 to 2000 IU daily. To achieve satisfactory vitamin D status (>30 ng/mL), many individuals may require higher doses. A similar suggestion was made at an expert roundtable discus- 
sion. The participants concluded that the intake of vitamin D should be at least $800 \mathrm{IU}$ daily ${ }^{[10]}$. In addition, this recommendation was independent of sun exposure, seasonal exposure and additional multivitamin use.

Calcitriol has been used as a therapy for osteoporosis for many years. One study verified that supplementation with calcitriol at $0.5 \mu \mathrm{g}$ per day for six months may promote bone formation and decrease bone absorption ${ }^{[28]}$. Active vitamin $\mathrm{D}$ analogs have a larger impact in decreasing bone loss and fracture incidence than standard vitamin D in postmenopausal osteoporosis because vitamin $\mathrm{D}$ analogs display a greater effect in reducing numbers of falls ${ }^{[29]}$. Calcitriol plays an important role in skeletal system regulation and may have other bone-protective effects independent of its calcium absorption effects $^{[30]}$. To prevent hypercalcinuria, patients with osteoporosis or osteopenia in China are frequently treated with 0.25 $\mu \mathrm{g} / \mathrm{d}$ of calcitriol ${ }^{[13]}$. After 3 months of intervention in our study, no differences were identified in calcium metabolism and bone turnover between the group treated with $0.25 \mu \mathrm{g}$ of calcitriol daily and the group treated with 800 IU of cholecalciferol daily. Serum calcium and AKP levels were significantly increased in both groups. The serum PTH and $\beta$-CTX levels were significantly decreased in both groups. However, the serum 25(OH)D level did not change significantly in the calcitriol group; it showed only a slight decreasing trend. Clements et $a l^{[31]}$ discovered that after supplementation with 1 $\mu \mathrm{g}$ per day of calcitriol to treat postmenopausal osteoporosis, hypoparathyroidism and hypophosphatemic osteomalacia, the elimination half-time for $25(\mathrm{OH}) \mathrm{D}$ in the plasma could be significantly shortened by raising the circulating concentration of 1,25-dihydroxyvitamin D. One explanation for this result is that calcitriol is the activated form of cholecalciferol, and excessive calcitriol decreases serum $25(\mathrm{OH})$ in a negative feedback system. Halloran et al ${ }^{[32]}$ discovered that rats chronically administered calcitriol displayed reduced serum concentrations of $25-\mathrm{OH}-\mathrm{D}_{3}$ and $24,25(\mathrm{OH})_{2} \mathrm{D}_{3}$ in a dose- and timedependent fashion. Calcitriol administration increased the metabolic clearance of 25-OH-D but not its production.

After 3 months of intervention, the concentration of serum $\mathrm{Ca}, \mathrm{P}$, and the total AKP activities in both groups remained within normal ranges. However, urinary calcium excretions were not observed in either group; this was a limitation of our study. In the United States, the previous NOF guidelines set the safe upper limit for vitamin D intake at 2000 IU per day. However, recent evidence has shown that higher intake is safe and that some older patients need at least this amount to maintain adequate 25(OH)D levels ${ }^{[8]}$. Doses of more than $50000 \mathrm{IU}$ of vitamin $\mathrm{D}_{3}$ per day are associated with hypercalcemia and hyperphosphatemia ${ }^{[33]}$. However, Vieth et $\mathrm{l}^{[34]}$ observed that doses of $10000 \mathrm{IU}$ of cholecalciferol daily for up to 5 months did not cause toxicity. In a randomized, double-blind trial that tested the efficacy and safety of zoledronic acid $(5 \mathrm{mg})$ that was intravenously supplemented annually in preventing new fractures in women and men who had hip fractures ${ }^{[35]}$, all the patients received oral calcium (1000-1500 $\mathrm{mg}$ ) and vitamin D (800-1200 IU) daily. By the end of the study, none of the patients suffered from hypercalcemia. These results indicate that the current safe upper intake level of $2000 \mathrm{IU}$ of vitamin D per day may be too conservative.

Our current study indicated that that cholecalciferol $(800$ IU/d) plus Caltrate D increased the mean serum 25(OH)D to $20 \mathrm{ng} / \mathrm{mL}$ in most but not all individuals. Both $800 \mathrm{IU} /$ day of cholecalciferol and $0.25 \mu \mathrm{g} /$ day of calcitriol plus Caltrate $\mathrm{D}$ effectively modified calcium and bone turnover markers in postmenopausal women in Shanghai with vitamin D insufficiency. The use cholecalciferol or calcitriol and the doses specified in the study for improving the bone health of postmenopausal women requires further investigation.

\section{Acknowledgements}

This study was supported by the National Natural Science Foundation of China (NSFC) (№ 30800387, 30771019, 81070692, 81170803), Academic Leaders in Health Sciences in Shanghai (XBR2011014), STCSM10DZ1950100, Science and Technology commission of Shanghai municipality (11ZR1427300) and Shanghai Rising Star Project (№ 11QA1404900).

\section{Author contribution}

Qi-ren HUANG designed this research; Hao ZHANG, Zhenlin ZHANG, Jie-mei GU, Wei-wei HU, and Yu-juan LIU performed clinical research; Qi-ren HUANG, Jie-mei GU, Yun-qiu $\mathrm{HU}$, and Yu-juan LIU recruited subjects; Hao ZHANG wrote the paper; and Qi-ren HUANG and Zhen-lin ZHANG revised the paper.

\section{References}

1 Holick MF. Vitamin D deficiency. N Engl J Med 2007; 357: 266-81.

2 Morales O, Samuelsson MK, Lindgren U, Haldosen LA. Effects of 1alpha,25-dihydroxyvitamin D3 and growth hormone on apoptosis and proliferation in UMR 106 osteoblast-like cells. Endocrinology 2004; 145: 87-94.

3 DeLuca HF. Overview of general physiologic features and functions of vitamin D. Am J Clin Nutr 2004; 80: 1689S-96S.

4 Thomas MK, Lloyd-Jones DM, Thadhani RI, Shaw AC, Deraska DJ, Kitch BT, et al. Hypovitaminosis D in medical inpatients. N Engl J Med 1998; 338: 777-83.

5 Dawson-Hughes B, Heaney RP, Holick MF, Lips P, Meunier PJ, Vieth R. Estimates of optimal vitamin D status. Osteoporos Int 2005; 16: 713-6.

6 Holick MF, Matsuoka LY, Wortsman J. Age, vitamin D, and solar ultraviolet. Lancet 1989; 2: 1104-5.

7 Weaver $\mathrm{CM}$, Fleet JC. Vitamin D requirements: current and future. Am J Clin Nutr 2004; 80: 1735S-9S.

8 Foundation NO. Clinician's Guide to Prevention and Treatment of Osteoporosis. Washington, DC: National Osteoporosis Foundation; 2010. Report №: 0029-6643 (Print) 0029-6643 (Linking).

9 Hanley DA, Cranney A, Jones G, Whiting SJ, Leslie WD. Vitamin D in adult health and disease: a review and guideline statement from Osteoporosis Canada (summary). CMAJ 2010; 182: 1315-9.

10 Roux C, Bischoff-Ferrari HA, Papapoulos SE, de Papp AE, West JA, Bouillon R. New insights into the role of vitamin $D$ and calcium in osteoporosis management: an expert roundtable discussion. Curr Med Res Opin 2008; 24: 1363-70. 
11 Heaney RP, Davies KM, Chen TC, Holick MF, Barger-Lux MJ. Human serum 25-hydroxycholecalciferol response to extended oral dosing with cholecalciferol. Am J Clin Nutr 2003; 77: 204-10.

12 Lau KH, Baylink DJ. Vitamin D therapy of osteoporosis: plain vitamin D therapy versus active vitamin D analog (D-hormone) therapy. Calcif Tissue Int 1999; 65: 295-306.

13 Xia WB, Zhang ZL, Wang HF, Meng XW, Zhang Y, Zhu GY, et al. The efficacy and safety of calcitriol and/or Caltrate $D$ in elderly Chinese women with low bone mass. Acta Pharmacol Sin 2009; 30: 372-8.

14 Holzherr ML, Retallack RW, Gutteridge DH, Price RI, Faulkner DL, Wilson SG, et al. Calcium absorption in postmenopausal osteoporosis: benefit of HRT plus calcitriol, but not HRT alone, in both malabsorbers and normal absorbers. Osteoporos Int 2000; 11: 43-51.

15 Richy F, Dukas L, Schacht E. Differential effects of D-hormone analogs and native vitamin $\mathrm{D}$ on the risk of falls: a comparative metaanalysis. Calcif Tissue Int 2008; 82: 102-7.

16 von Hurst PR, Stonehouse W, Kruger MC, Coad J. Vitamin D supplementation suppresses age-induced bone turnover in older women who are vitamin D deficient. J Steroid Biochem Mol Biol 2010; 121: 293-6.

17 Seamans KM, Hill TR, Wallace JM, Horigan G, Lucey AJ, Barnes MS, et al. Cholecalciferol supplementation throughout winter does not affect markers of bone turnover in healthy young and elderly adults. J Nutr 2010; 140: 454-60.

18 Holick MF, Siris ES, Binkley N, Beard MK, Khan A, Katzer JT, et al. Prevalence of vitamin $D$ inadequacy among postmenopausal North American women receiving osteoporosis therapy. J Clin Endocrinol Metab 2005; 90: 3215-24.

19 Lips P, Hosking D, Lippuner K, Norquist JM, Wehren L, Maalouf G, et al. The prevalence of vitamin $D$ inadequacy amongst women with osteoporosis: an international epidemiological investigation. J Intern Med 2006; 260: 245-54.

20 Heaney RP, Dowell MS, Hale CA, Bendich A. Calcium absorption varies within the reference range for serum 25-hydroxyvitamin D. J Am Coll Nutr 2003; 22: 142-6.

21 Kuwabara A, Tsugawa N, Tanaka K, Fujii M, Kawai N, Mukae S, et al. Improvement of vitamin $\mathrm{D}$ status in Japanese institutionalized elderly by supplementation with 800 IU of vitamin D(3). J Nutr Sci Vitaminol (Tokyo) 2009; 55: 453-8.

22 Ravn P, Fledelius C, Rosenquist C, Overgaard K, Christiansen C. High bone turnover is associated with low bone mass in both pre- and postmenopausal women. Bone 1996; 19: 291-8.

23 Seeman E, Delmas PD. Bone quality - the material and structural basis of bone strength and fragility. N Engl J Med 2006; 354: 225061.

24 Eastell R, Hannon RA. Biomarkers of bone health and osteoporosis risk. Proc Nutr Soc 2008; 67: 157-62.

25 Bischoff-Ferrari HA, Willett WC, Wong JB, Giovannucci E, Dietrich T, Dawson-Hughes $B$. Fracture prevention with vitamin $D$ supplementation: a meta-analysis of randomized controlled trials. JAMA 2005; 293: 2257-64.

26 Pignotti GA, Genaro PS, Pinheiro MM, Szejnfeld VL, Martini LA. Is a lower dose of vitamin D supplementation enough to increase $25(\mathrm{OH}) \mathrm{D}$ status in a sunny country? Eur J Nutr 2010; 49: 277-83.

27 Chapuy MC, Pamphile R, Paris E, Kempf C, Schlichting M, Arnaud S, et al. Combined calcium and vitamin D3 supplementation in elderly women: confirmation of reversal of secondary hyperparathyroidism and hip fracture risk: the Decalyos II study. Osteoporos Int 2002; 13: 257-64.

28 Tsukamoto Y, Watanabe T, Nakagami T, Morishita K. Effect of treatment with oral calcitriol on calcium metabolism and fasting serum $25(\mathrm{OH})$ - or $1,25(\mathrm{OH})_{2}$-vitamin D level in Japanese postmenopausal women. Endocr J 2003; 50: 681-7.

29 Schacht E, Richy F, Reginster JY. The therapeutic effects of alfacalcidol on bone strength, muscle metabolism and prevention of falls and fractures. J Musculoskelet Neuronal Interact 2005; 5: 273-84.

30 Richy F, Ethgen O, Bruyere O, Reginster JY. Efficacy of alphacalcidol and calcitriol in primary and corticosteroid-induced osteoporosis: a meta-analysis of their effects on bone mineral density and fracture rate. Osteoporos Int 2004; 15: 301-10.

31 Clements MR, Davies M, Hayes ME, Hickey CD, Lumb GA, Mawer $E B$, et al. The role of 1,25-dihydroxyvitamin $D$ in the mechanism of acquired vitamin D deficiency. Clin Endocrinol (Oxf) 1992; 37: 17-27.

32 Halloran BP, Bikle DD, Levens MJ, Castro ME, Globus RK, Holton E. Chronic 1,25-dihydroxyvitamin D3 administration in the rat reduces the serum concentration of 25-hydroxyvitamin D by increasing metabolic clearance rate. J Clin Invest 1986; 78: 622-8.

33 Koutkia P, Chen TC, Holick MF. Vitamin D intoxication associated with an over-the-counter supplement. N Engl J Med 2001; 345: 66-7.

34 Vieth R. Why the optimal requirement for vitamin D3 is probably much higher than what is officially recommended for adults. J Steroid Biochem Mol Biol 2004; 89-90: 575-9.

35 Lyles KW, Colon-Emeric CS, Magaziner JS, Adachi JD, Pieper CF, Mautalen $\mathrm{C}$, et al. Zoledronic acid and clinical fractures and mortality after hip fracture. N Engl J Med 2007; 357: 1799-809. 